\title{
Evaluation of High-Quality Foreign Trade's Development
}

\author{
Guirong Jiang 1,a,b* TaoLi ${ }^{2, b}$ \\ ${ }^{a}$ College of Economics, Southwest Minzu University, Chengdu, Sichuan \\ ${ }^{b}$ College of Economics and Management, Tarim University, Alaer, Xinjiang \\ * Guirong Jiang. Email:71742649@qq.com
}

\begin{abstract}
Using the analytic hierarchy process, this paper puts 15 indexes in 4 dimensions to evaluate the high-quality development of foreign trade based on the review of existing literature on the evaluation indexes of foreign trade quality, and takes foreign trade in Xinjiang from 2014 to 2017 as an empirical study. it is concluded that Xinjiang should focus on the two dimensions of foreign trade transformation and innovation cultivation in the future, and then put forward countermeasures and suggestions to promote the high-quality development of foreign trade in Xinjiang.
\end{abstract}

Keywords: Xinjiang's Foreign Trade, High-quality development, Evaluation

\section{INTRODUCTION}

In accordance with the spirit of the 19th CPC national congress, the central economic work conference held in December 2017 concluded that "socialism with Chinese characteristics has entered a new era and China's economic development has entered a new era. The high-quality development of economy cannot leave the high-quality development of foreign trade, so how to measure the quality of foreign trade development of a country (region)? This paper reviews the existing literature on foreign trade quality evaluation indicators, proposes the following 4 dimensions and 15 indicators to evaluate the high-quality development of foreign trade, took foreign trade in Xinjiang as an empirical study.

\section{INDEX SYSTEM AND EVALUATION METHODS}

\subsection{High-quality Development Indicator System For Foreign Trade}

In order to evaluate the overall development situation, development forms and achievements of foreign trade, this paper will construct 4 second-level indicators and 15 third-level indicators from the four dimensions of coordinated development, transformation development, harmonious development and innovative development. Through the calculation and summary of the three levels, the first level index of the development quality of foreign trade is finally obtained, and the overall assessment of the development quality of foreign trade is made according to the change of the score of the first level index ${ }^{[1]}$. Specific indicators are as follows:

Table 1. Quality evaluation system of foreign trade development

\begin{tabular}{llllll}
\hline \multicolumn{2}{l}{ Secondary Indicator } & \multicolumn{2}{l}{ Tertiary Indicator } & \\
\hline Index Name & Code & Index Name & code & Properties \\
& & Foreign Trade Dependence & & \\
$\begin{array}{l}\text { Coordinated } \\
\text { Development }\end{array}$ & $Z_{1}$ & Net Exported Development Index & $\mathrm{C}_{1}$ & Appropriate Index \\
& & & $\mathrm{C}_{2}$ & Positive Index \\
\hline
\end{tabular}




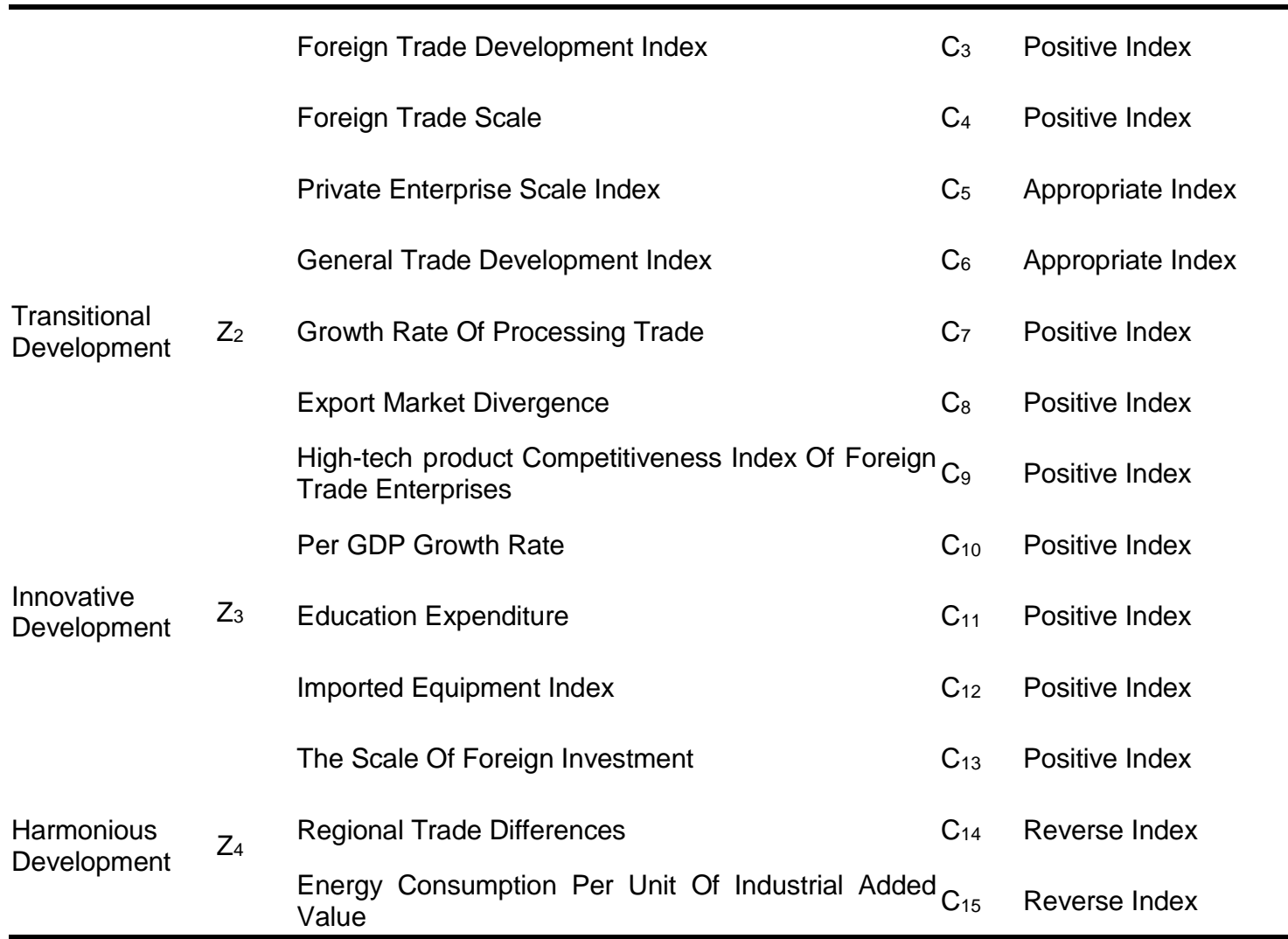

\subsection{Introduction of Evaluation Methods}

Because each index has different influence on the development quality of foreign trade, it is necessary to assign different weight to each index. This paper will use analytic hierarchy process (AHP) to determine index weight, namely in the domestic research about this article selects index of judge matrix and test principle, using hierarchical analysis software YAAHP specific calculation software input its judgment ${ }^{[2]}$, based on the analytic hierarchy process (AHP) process, determining the weight of each index can be obtained as a result, the corresponding weight vector according to the calculation and test software consistency ratio at the same time, the ratio is less than 0.1 , says the results acceptable ${ }^{[3]}$; Secondly, through it, the comprehensive weight of the secondary index and the comprehensive weight of the primary index are obtained. Finally, the weight of each indicator is used to calculate the score of each indicator, and gradually summarized to form the score of each level, and finally the overall score of the development quality of foreign trade is obtained.

\section{TAKING XINJIANG'S FOREIGN TRADE AS AN EXAMPLE}

\subsection{Index Weight}

According to the determination method of index weight in analytic hierarchy process, the weight of Xinjiang's foreign trade development quality evaluation system is calculated by software, as shown in table 2 below.

Table 2. Index Weight of Xinjiang foreign trade development quality

\begin{tabular}{llll}
\hline Secondary Indicator & Tertiary Indicator & \\
\hline Index Name & Weight & Index Name & Weight \\
& & Foreign Trade Dependence & 0.0191 \\
Coordinated & 0.2832 & Net Exported Development Index & 0.0650 \\
Development & & Foreign Trade Development Index & 0.0386
\end{tabular}




\begin{tabular}{|c|c|c|c|}
\hline & & Foreign Trade Scale & 0.0345 \\
\hline & & Private Enterprise Scale Index & 0.1259 \\
\hline & & General Trade Development Index & 0.0175 \\
\hline $\begin{array}{l}\text { Transitional } \\
\text { Development }\end{array}$ & 0.1651 & Growth Rate Of Processing Trade & 0.0430 \\
\hline & & Export Market Divergence & 0.1046 \\
\hline & & $\begin{array}{l}\text { High-tech product Competitiveness Index Of Foreign } \\
\text { Trade Enterprises }\end{array}$ & 0.20 \\
\hline & 04445 & Per GDP Growth Rate & 0.0627 \\
\hline Development & טרום ד. & Education Expenditure & 0.0627 \\
\hline & & Imported Equipment Index & 0.1169 \\
\hline & & The Scale Of Foreign Investment & 0.0214 \\
\hline $\begin{array}{l}\text { Harmonious } \\
\text { Development }\end{array}$ & 0.1072 & Regional Trade Differences & 0.0214 \\
\hline & & $\begin{array}{l}\text { Energy Consumption Per Unit Of Industrial Added } \\
\text { Value }\end{array}$ & 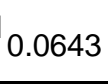 \\
\hline
\end{tabular}

The index weight consistency ratio is 0.0267 , indicating that the result is acceptable. The results show that in the process of foreign trade development in Xinjiang, the highest weight of innovative development is 0.4445 , followed by coordinated development is 0.2832 , followed by transformation development, followed by harmonious development. This specific gravity arrangement shows. In the development of Xinjiang's foreign trade, innovation has the greatest influence on it, while harmonious development has less impact on the overall development of foreign trade.

\subsection{Dimensionless Treatment of Indicators}

Due to the different roles of indicators, there are

Table 3. The dimensionless results of positive index

\begin{tabular}{lllll}
\hline Index Name & 2014 & 2015 & 2016 & 2017 \\
\hline Net Exported Development Index & 60.07 & 79.38 & 60.83 & 60.05 \\
Foreign Trade Development Index & 60.01 & 78.31 & 60.00 & 60.12 \\
Foreign Trade Scale & 60.01 & 79.16 & 60.46 & 60.00 \\
Growth Rate Of Processing Trade & 62.59 & 82.89 & 63.50 & 60.63 \\
Export Market Divergence & 60.79 & 79.84 & 63.27 & 60.39 \\
High-tech product Competitiveness Index Of 60.37 & 100.00 & 79.74 & 61.41 & 60.23 \\
Foreign Trade Enterprises & 68.38 & 60.00 & 77.15 & 100.00 \\
Per GDP Growth Rate & 60.52 & 80.15 & 100.00 & 66.84 \\
Education Expenditure & 60.00 & 79.17 & 62.75 & 60.27 \\
Imported Equipment Index & & 60.46 & 60.01 \\
The Scale Of Foreign Investment & & & \\
\hline
\end{tabular}


3.2.2. Dimensionless Inverse Index

$$
W=40 \times \frac{Z_{\text {max }}-Z}{Z_{\text {max }}-Z_{\text {min }}}+60
$$

Table 4. The dimensionless results of inverse index

\begin{tabular}{lclll}
\hline Index Name & 2014 & 2015 & 2016 & 2017 \\
\hline Regional Trade Differences & 99.95 & 80.81 & 99.48 & 99.98 \\
$\begin{array}{l}\text { Energy Consumption Per Unit } \\
\text { Industrial Added Value }\end{array}$ & 100.00 & 80.85 & 99.56 & 100.00 \\
\hline
\end{tabular}

\subsubsection{Dimensionless Moderation Index}

$$
\begin{aligned}
& \mathrm{W}=40 \times \frac{Z_{\text {max }}-Z}{Z_{\text {max }}-Z_{m}}+60 \\
& Z_{\mathrm{m}} \leq Z<Z_{\text {max }}
\end{aligned}
$$

quantitative index, $\mathrm{Z}$ represents the value of the original index data, $Z_{\min }$ represents the minimum value of the index in the original data, $\mathrm{Z}_{\mathrm{m}}$ represents the moderate value of the index in the original data, and $Z_{\max }$ represents the maximum value of the index in the original data ${ }^{[5]}$.

Where, We represents the evaluation value of the

Table 5. The dimensionless results of moderate index

\begin{tabular}{lllll}
\hline Index Name & 2014 & 2015 & 2016 & 2017 \\
\hline Foreign Trade Dependence & 86.32 & 100.00 & 90.38 & 78.73 \\
Private Enterprise Scale Index & 99.20 & 95.77 & 96.36 & 99.48 \\
General Trade Development Index & 99.84 & 98.33 & 99.39 & 100.00
\end{tabular}

\subsection{High Quality Development Index of The weighted sum of the four secondary indicators Xinjiang's Foreign Trade was calculated, and the scores were shown in table 6.}

Table 6. The Secondary index of high-quality development for Xinjiang's foreign trade

\begin{tabular}{lllll}
\hline Secondary Index & 2014 & 2015 & 2016 & 2017 \\
\hline Coordinated Development & 79.23 & 87.89 & 78.47 & 78.86 \\
Transitional Development & 65.41 & 82.60 & 67.17 & 64.66 \\
Innovative Development & 67.12 & 79.91 & 69.42 & 66.78 \\
Harmonious Development & 91.99 & 80.50 & 91.72 & 92.00 \\
\hline
\end{tabular}

Finally, the high quality development index of Xinjiang's foreign trade is calculated by the weighted sum of the secondary index, and its development trend is shown in figure 1.

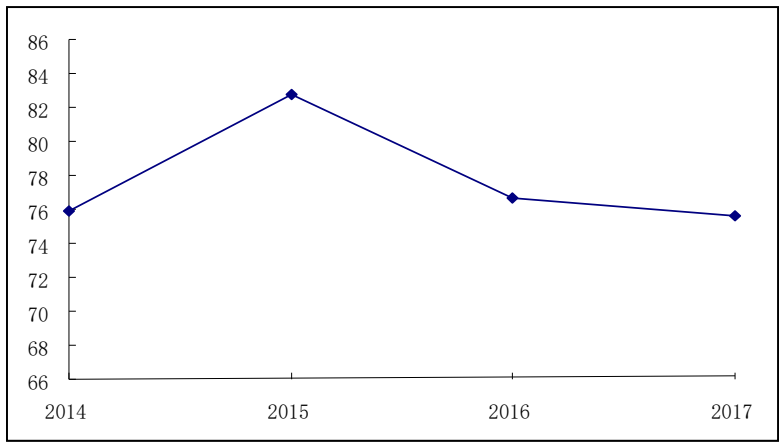

Figure 1 High-quality development index of Xinjiang's foreign trade

As can be seen from figure 1, the quality index of Xinjiang's foreign trade development has been greatly improved from 2014 to 2015 , from 72.94 points in 2014 
to 82.68 points in 2015 . From 2015 to 2016 , the score decreased from 82.68 in 2015 to 74.00 in 2016 . The quality of foreign trade development was somewhat stable in 2017. According to the analysis of the 4-year index changes, the quality index of Xinjiang's foreign trade development fluctuates greatly during the 4-year period, rising significantly in the previous two years, decreasing significantly from 2015 to 2016, remaining unchanged from 2016 to 2017, and finally the overall quality index tends to be stable.

\section{RESULTS}

(1) From 2014 to 2017, the development trend of innovation, coordination and transformation in Xinjiang's foreign trade development is roughly the same, and tends to be consistent with the overall development quality trend of Xinjiang's foreign trade. The harmonious development did well, with the highest average level, but the trend of change was exactly opposite to the overall trend of the quality of Xinjiang's foreign trade development, indicating that the influence of the dimension of harmonious development on the quality of Xinjiang's foreign trade development is limited.

(2) In the future development of Xinjiang's foreign trade, we should first pay attention to the transformation of foreign trade and the cultivation of innovation.

(3) From 2014 to 2017, the quality of Xinjiang's foreign trade development did not improve significantly, although it reached a high point in 2015.

In order to better improve the development quality of Xinjiang's foreign trade, according to the development status of the four dimensions, combined with Xinjiang's foreign trade development reality and development goals, the following countermeasures are proposed.

(1) Accelerating the development of foreign trade. Xinjiang's foreign trade should seize the policy opportunity of "One Belt And One Road" to enhance the strength of foreign trade development and increase the export income of foreign trade. ${ }^{[6]}$ In foreign trade, while speeding up the development of foreign trade, we must pay attention to the principle of sustainable development in the production process.

(2) Promote the export of high-tech products and increase foreign exchange earnings. ${ }^{[7]}$ In the process of foreign trade, we should pay attention to the practical benefits and specific product benefits, promote coordination and balance, and maintain the growth potential of steady development. In other words, we will steadily develop technology-intensive export products, steadily raise the price level of export products, and increase the value added of foreign trade. In the process of foreign trade, we should see the potential of developing XinJiang's service trade. Finally, in order to cope with the advantages of Xinjiang's foreign trade products, we will steadily improve the technological content and product advantages, develop emerging industries and strengthen the advantages of foreign trade products.

(3) Promoting the transformation and upgrading of processing trade and enhance the innovation ability of foreign trade enterprises. It is necessary to promote the development of Xinjiang's foreign trade by improving processing trade, especially for products with high value-added rate of processing trade. Improve the trade form, introduce and train foreign trade talents, establish convenient foreign trade access, achieve steady and high-quality development of Xinjiang's foreign trade.

\section{CONCLUSION}

Use in Urumqi, Xinjiang statistical yearbook and customs statistics yearbook data, on the Xinjiang foreign trade development health using the hierarchical analysis method, the analysis found the Xinjiang foreign trade development, in the process of large fluctuations, foreign trade development situation need to improve, need to pay attention to the innovation and development, the transformation of development and the coordinated development of the important role, increase spending on the three aspects, establish a good momentum of development, promote the rapid healthy progress of Xinjiang foreign trade development, improve the Xinjiang foreign trade development, at the same time to keep steadily in the Xinjiang foreign trade development the good situation of harmonious development, We should seize the development opportunities brought by the support of "One Belt And One Road" and other countries, realize the rapid and healthy development of Xinjiang's foreign trade and establish a good development momentum.

\section{AUTHORS' CONTRIBUTIONS}

This paper is one of the phased achievements of the Western Project of National Social Science Foundation of China (No. 19XJY009).

\section{REFERENCES}

[1] J. Chen, B.Y Zhang, Review on evaluation index of sustainable development of foreign trade -- also on the construction of evaluation index system of sustainable development of service trade. Journal of Xidian University (social science edition), 2014, pp. 27-32.

[2] Z.H. Gu, Evaluation system and model of the sustainable foreign trade development. Statistics and Decision-making, 2005, pp. 40-45. 
[3] G.G. Gao, Study on the method of index weight determination and score conversion in multi-index comprehensive evaluation. Economist, 2003, pp. 55-60.

[4] X.Y. Tang, The effect of foreign trade on China's economic growth. China Business Theory, 2016, pp. 35-41.

[5] X.Q. Wang, Research on Xinjiang's dependence on foreign trade under the new silk-road economic belt. Contemporary Economics, 2016, pp. 66-72.

[6] H. Zhang, Transformation and adjustment of China's foreign trade strategy since the reform and opening up. Market Weekly, 2018, pp. 115-119.

[7] X.X. Zhao, Research on the development mode of Xinjiang's foreign trade under the background of "new normal". Journal of Guizhou Business School, 2016, pp. 35-41. 